つ社の局ゆ通いるす言れなう

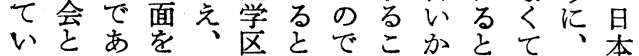

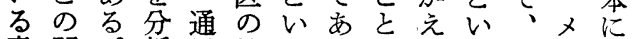

意関。析学社えるにれう子ン沶

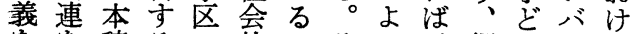

学稿るの的のそっ網も1る

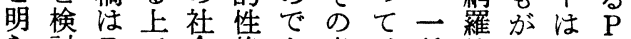

ら. 討 $\mathrm{P}$ で会格あ意、種的当自 $\mathrm{T}$

加し T、的老る味自の・該登 A

に、 $\mathrm{A}$ 二性何。で動施強の的注

乙子飞定格 $5 し は$ 的設制学意、

よりそのをかた、に利的校志こ

うわれ有検のが P P 用加ににれ

とけが効討程っ T T 圈入在よま

卞流々性守度て A A で方籍っで

る動のをる反、はメあ式寻て繰

も的上もこ映 $\mathrm{P}$ 地

の地につと守 $\mathrm{T}$ 縁バをよだこか

で域成でがるA的１こっけに光 あに立あ、岳基シろてで参し るお方方 $\mathrm{P}$ 予、礎少成自加指 けるう $\mathrm{T}$ 想その プ通立動し摘 るととA A の上が学立的て商 $\mathrm{P} こ$ 推にれ基に付区て应的 T万测関る礎成与内い会るて A のさ主。立せにる貝のき が地れるそす方居号完でた

究

流

動

地

域

に

お

け

る

$\mathrm{P}$

も域る一れるてれ住ささはな

に活二のえる的中父とてをなは

都様ズがで隹でしい並地どわそ問 市式么、它都大、方存域のなれ題 のとしこ出市きつ称枠し社よけがを

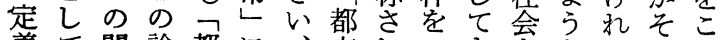
義て関論都に、市れ設き索な壮のの との連文市特永らる定た対枠な上よ

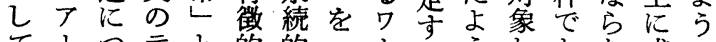
$\tau 1 つ テ と$ 的的 提バい1 伛な社スこにすらい立設

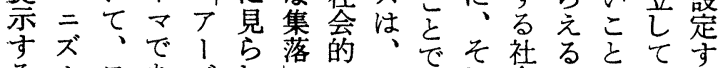
る厶必の市っ

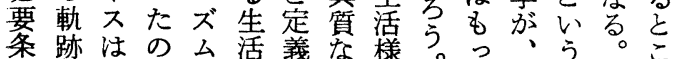

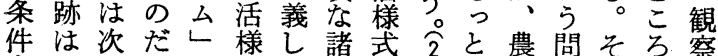
を、のろの武た個とさ年村題こ令祭

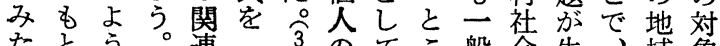
たとう連 そ氜のてこ般会生、域象

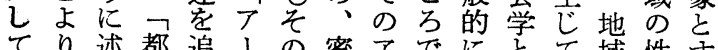
てり述都追1の密厂でにとて域性す いわべ市求バよ度、フ都く社格る るれてしし二うのバ都、市る会に $\mathrm{P}$ 場わいとよズにあ二市農社。会対 $\mathrm{T}$

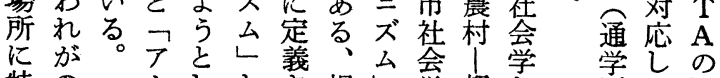

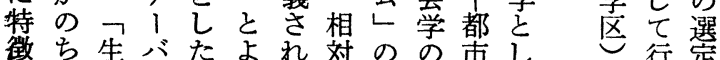

日

耕

夫 
てのそ性のをせはのこっの市バと意とつるの半に域的 も異れの中捨て石異とこ理“云味をアの範はで性に 、質と低に象み定質にの解のズでで逆! は囲、もに見

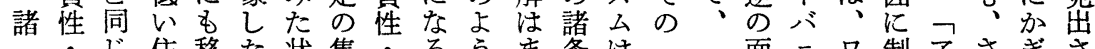

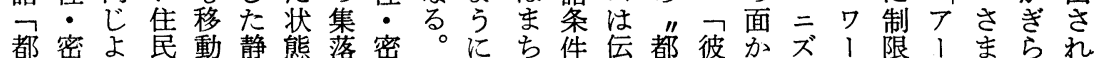

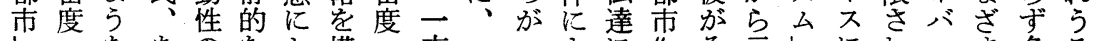

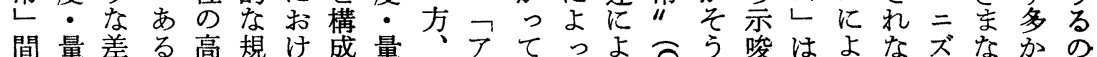

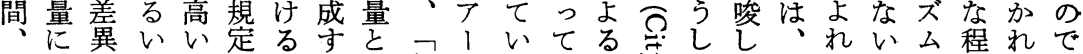
およはは住で規るい都バな規漫怘たた基ばこし度少あ

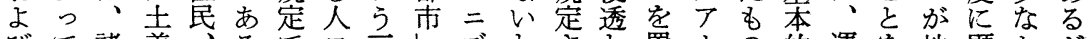

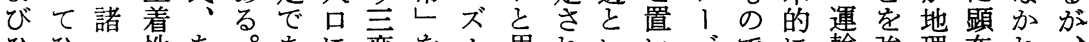
ひひ性あ。あに変をム思れいいバでに輸強理在れ、

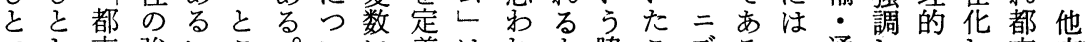
つし市強いこ。いに義はれも脇こズる・通し・し市方 のくレいはろそてつすつるの道とムと都信て物ての丁 ᄀ只地流での、いる都官でをはの考市にい理い影 都都間域動、意そてた市もあ除明基えしよる的る響心 市市にと性あ味の考めしる外ら盤る.にっの空ら。怘二

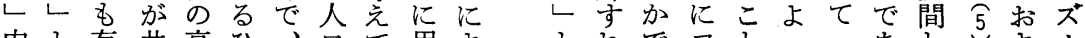

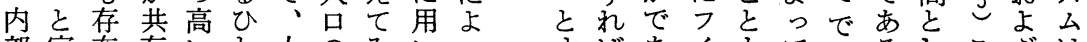

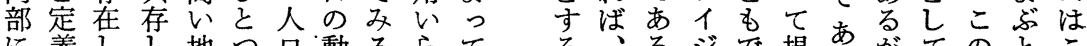

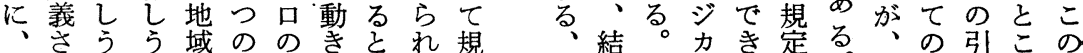

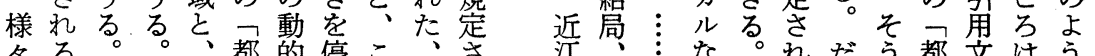

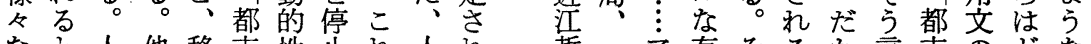

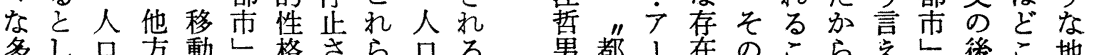
多し口方動し格さら口る男都 1 在のこら光し後こ地

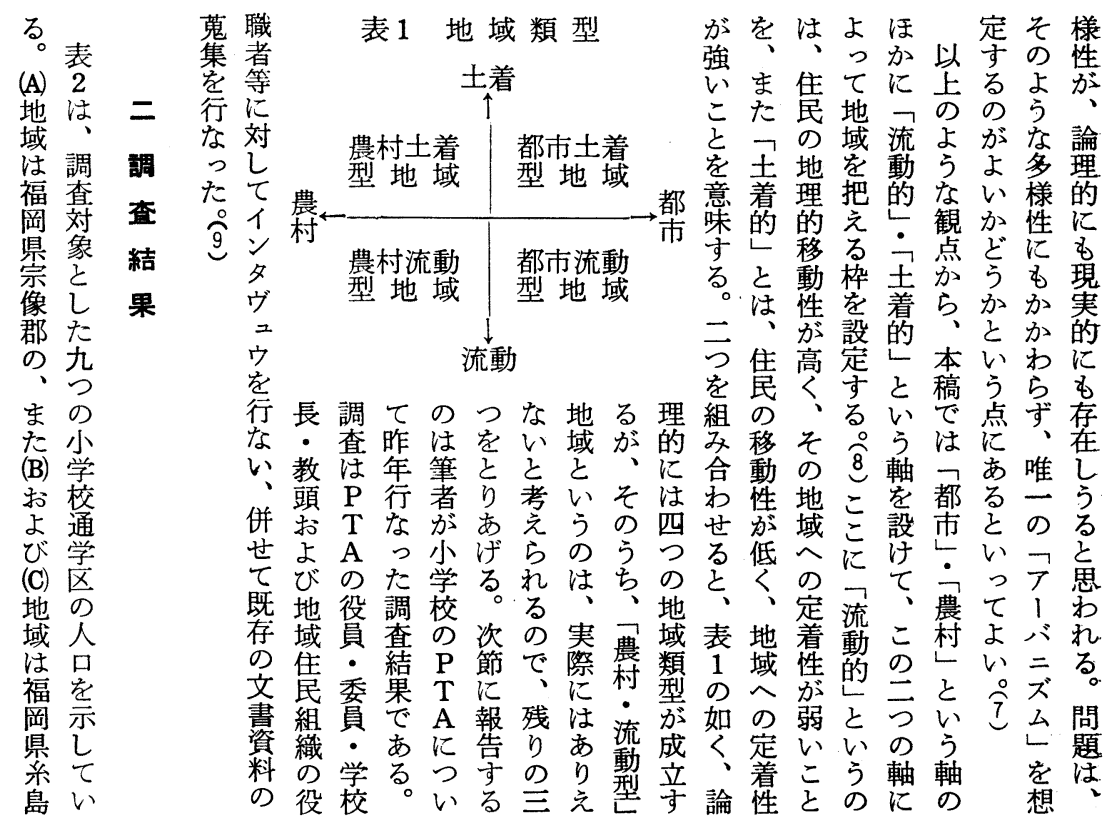


流動地域におけるPTAの意義について

表 2 対象地域の人口

\begin{tabular}{|c|c|c|c|c|c|c|}
\hline 地 & 域 & S. 35 & S. 39 & S. 40 & S. 43 & S. 45 \\
\hline A & (a) & - & - & 4,108 & 3,702 & - \\
\hline B & (b) & - & 2,940 & - & - & 2,576 \\
\hline $\mathrm{C}$ & (b) & - & 5,950 & - & - & 5,270 \\
\hline $\mathrm{D}$ & (c) & 10,826 & - & 9,446 & - & 8,070 \\
\hline $\mathrm{E}$ & (c) & 12,357 & - & 9,238 & - & 6,336 \\
\hline $\mathrm{F}$ & (c) & 13,367 & - & 11,787 & - & 8,616 \\
\hline G & (c) & 5,860 & - & 8,070 & - & 9,055 \\
\hline $\mathrm{H}$ & (c) & 2,776 & - & 7,676 & & 11,988 \\
\hline I & (c) & - & - & - & - & 9,212 \\
\hline
\end{tabular}

(注) (a)：矢野峻ほか「都市近接農村における教育 要求のパターン」九州大学教育学部紀要 第14集 1969 年, p. 110

(b) : S. 39年は糸島郡前原町総務課調べ， S. 45 年は国勢調查より

(c) : S. 35，S.40 は福岡市総務部統計課厂福岡 市人口白書一昭和 40 年国勢調查の結果」 p.11より，S.45は同「福岡市町名別人口 一昭和 45 年国勢調查結果」 $\mathrm{p} .2$ より
六間従に農このが郡 六借業隣 (D) 㯲の割主要

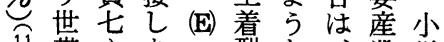

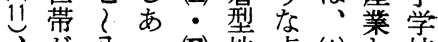
が分口(F) 地点 (A) そ校 移五人たの域分。な通 動割以小主年

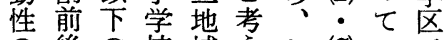
の後の校域えこ(C) いで 高に小通はての順るあ

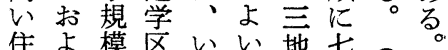
隹び模芯ずだ域厹第人 が営あれろ考市口

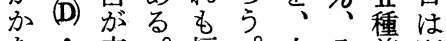
な (E) 噼。福。土公兼漸 配こ岡着示業減 存 (F) 的市市泉\%委し 年順商の中蒙七含つ るに業地心世思市 こ四軍域部带\%るる

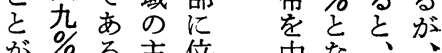
㤎\%る卦位中な 中. 予四。要置心る農な

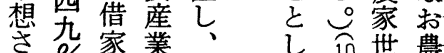
さ京業互た记世带業

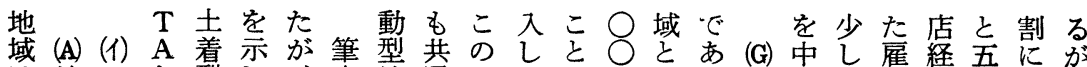

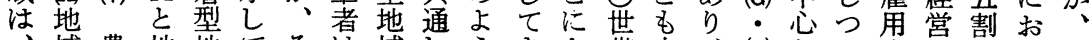

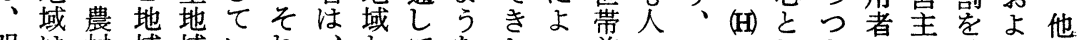

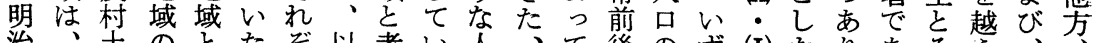
治、士のたぞ以考い人移て後のず（I）たりあそ充、

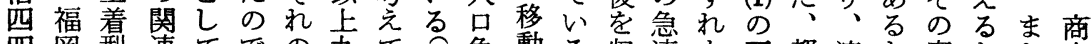

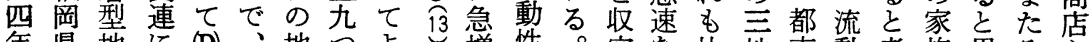
年県地飞 (D) 地つょ。增性穴な比地市動考族思飞主

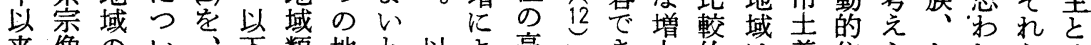
来像の

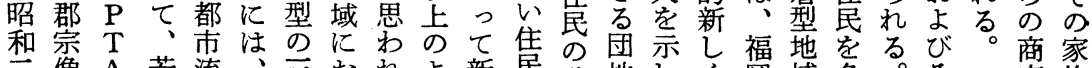

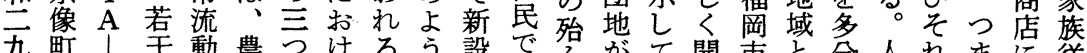

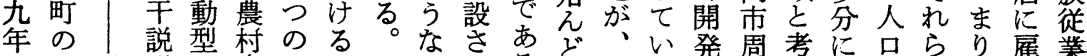

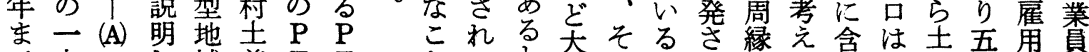

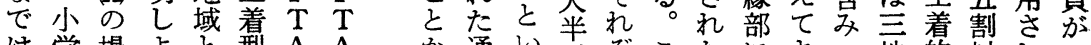
は学場よと型 A A か通いがぞこたによう地以れこ

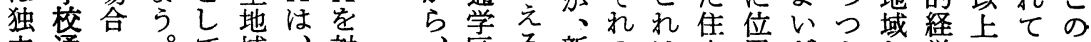

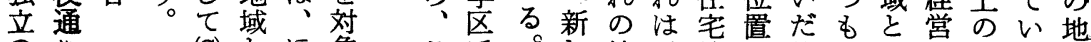
の学 (G) そほ象こでこし地、地守る、も泉る域

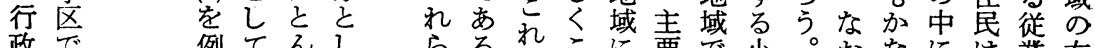

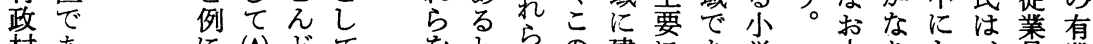

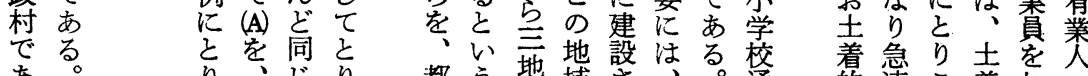
あこり都傾京蒂点域域さ、。通 たの P都傾离 流点域流たの杂学

的速こ着加口 住にま的えの 民減れ商るき 
四 1 (A) P T A 役員委員の選出方法

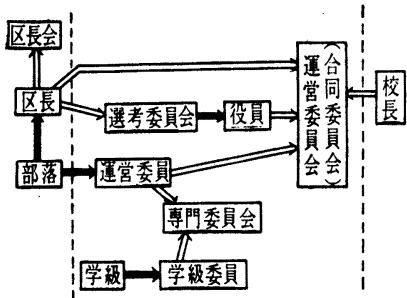

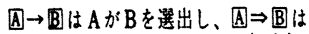

AはBのメンバーになることを示す。(以下同し)
(A) 連きさ固戦瑟ばな機こる。のが

$\mathrm{P}$ 組。て資導、(A) 能の 部同

$\mathrm{T}$ 織こい産員会地を地に年

でづれる評計域累域な言

はくの、委済查のさーたに

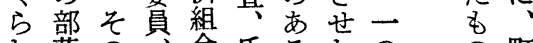

通れ落の合氏るたのの町

学てをよ交総子部基部で村

区お基う通代総落礎落六

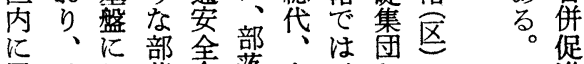

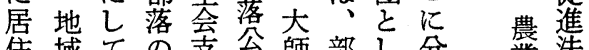

住域て䍃公師部し分業法

寸全、性部氐様落てれ委に

る体 (A) 格長館世集のる 主基

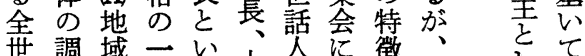

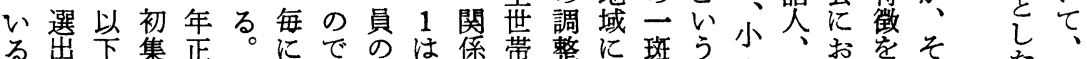

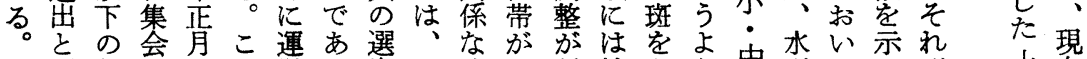
こ同部亡にれ営る出 $\mathrm{P}<$ 行校うう中学引てしぞ严在 の時落に開は委。方 T会子な区名な学人、てれ 着の 部に組おか、頜ま法 $\mathrm{A}$ 員ぞわ区が役関、区いの 型よ 落行織いれ各㤎ずをのにもれ長う職简粐長る。部のう 選な役てる部選、示役なのて会こ者俰摺補。落地に 出わ職、落出各し員る。有いと㤎補者会た注域宗

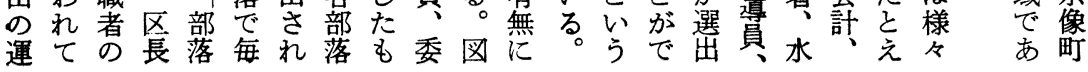

学く T只か同、方をい中な部拿かに員計作営 校る $\mathrm{P} A$ 部会 $5 \mathrm{P} P$ 人。T担落に選 $\mathrm{T} T$ の (A) A 当組部 ば A A 奉 $\mathrm{P}$ と部織落れの役 仕 T部落の区て中員 作 A 落委役長W心 業でと貝職功る的委 为はのと者参こ役買 重つこしで加と割の 要校のてあし、選 な区よのるてお担出 一奉亏性がいよっ方 活仕な格、るびて法 動作関を部こ、いを 乞業係与落々扗る以 乙边選艻運上 てと次ら出注運営の 組しのれの目営委よ まてょて運さ委員う れ、うい営れ貝会に て $\mathrm{P}$ な委る会の検 い下 形の員。文メ討 るA ででも欧いンし 例頜現るい浮る、み 年にわ。わも合がる 同よれ价咼部と、 ごるて $\mathrm{P}$ 委落

ぎ運るにも落他同れおと監ら委 な営の運の選方委るけ $\mathrm{P}$ 查れ梖

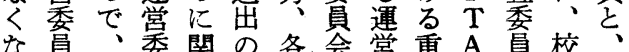
り会形員守運学崣要役等長部 、荗式会る営級い筫な員の・落 $\mathrm{P}$ 代上の専委をう会決打 $\mathrm{P}$ 教長 $\mathrm{T}$ 行 A し 専 ン委と位称、び $\mathrm{A}$ を に、門バ䆩とにで前遂校役協る おそ委 I 会もしよ記行長員議区 いの貝でをにてばのをにをの長 て結会あ構、、れメ担よ選上と 重果染る成企学てンっっ出でに 要、担部与画級いバててす会よ な專当落る。委る 1 い運る。長つ 役門守選。予貝 割委る出し算唯 は員この加選

ほ会と運し成出 と治に営、人さ え名な委各教れ
ぞ眘つ筫専充

果上て㤎閏之学

しのい加委い級

七もるわ貴う委

心の活?会文貞 なに動てのう注
更営更副 $\mathrm{P}$ に $\mathrm{P}$ 䆩に会 $\mathrm{T}$ 一 $\mathrm{T}$ 会、長 $\mathrm{A}$ 一A 部役 人総編落会員 の会成選計選 区長直出出書委 前 $\mathrm{P}$ 運記貣 加に $\mathrm{T}$ 営会 え開 $\mathrm{A}$ 委会芳 
り (A)てて出行りとて学なっの合わわたをるそ期なでよ 部地るたれうなう落あてのに不てれてるつぞ各て日な 落域と場るこくよ $\mathrm{P}$ るよ繰参いるはチをれ部い程内 かでい合。と、う下部るうり加る。 らはっ以と両な $\mathrm{A}$ 落がに入料世通子ン、部に。決の のこて $\mathrm{P}$ 上さ親行活で、(A) れが带学ぞネ運落指運定仕 構のよ下はれも事動はこ地ら課も距もル営の示営だ事

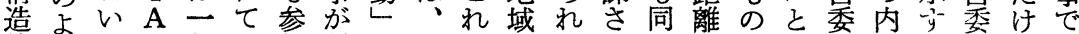
的うよは例い加行ととをにるれ様の有し貝部る貝が 分にう部をるしなしの部お。命るに関無て会事と会問各 华 $\mathrm{P}$ 落挙。てわて部落い年。参係に機は情部に題部 が $\mathrm{P}$ 思のげそ、れ、落のて金加で関能、落おに落

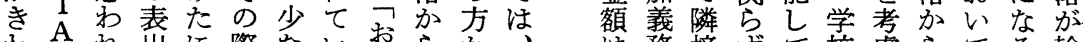
わ和出飞際ないお斿、 めがる的要注くるこ選 $5 \mathrm{P}$ 七部。川ぎ、年出出 $\mathrm{T}$ 不落統な部を、りさ思 完組合い落目こしれとと 全織的が費標元海た次部 なの行、のとら海運の落 形中事部中乞海永営よの

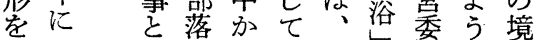
と解しにらは子貝に界 っ消て焦経部ぞ々をなが てさ位点費落も冬中る不 いれ置を補繀達至心。明 るて ら゙あ助出ば岕りにた瞭 注務接ず校慮らてる輪 一をの、い側し選、。番

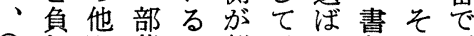
$\bigcirc$ わ町落の部、れ記の行 $\bigcirc$ さ村ので落奉て教決な ○洦全あに仕き教定う 円て小世対作七頭のこ でお学帯。し業いが仕亡 り校が作てのる大方に そ、に参業、日運まはな れ不子加の了時営か次っ は参ぞ義実解定委にのて 部加も務施・回員担よい 落のを学に承答が当うる 費場通負あ諾学、時にの

\section{図 2 (D) P T A 役員・委員の選出方法}

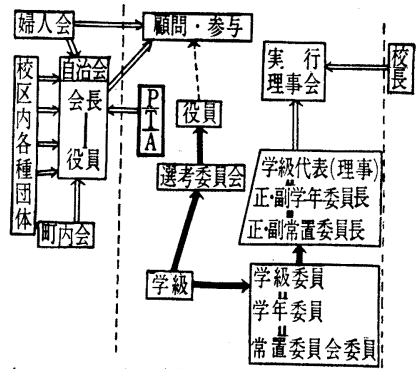

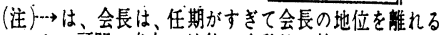
と、碩問・参与の地位に自動的に就くことを示す。

の兼て異ン老はつあ易

例任おっバ人校るの (D) (口) 外守りて 1 ク二区。時地

はる、いとラ三連こ代域都 あこ二るしブの合のには市

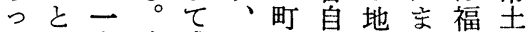
てに人連成そ内治域で岡着 もなの合立の会会にさ市型 っ 町自己他のし涪中地

殆て内治てのほと二の心域

んい会会い、か称二ぼ部の

ぞる長にる (D) に古のるに $\mathrm{P}$

は、注。地、る町と位 $\mathrm{T}$ 町こ会そ域防上内部 $\mathrm{A}$ 内れ長の内犯部会わ表। 会 長の副点存合織あるての 商贯連会、在吕織あ伝小場 自連合長単梦遺でり、統学合 臬合自々なる族きを町を校 営自治のるい会七町文通 員におうれバフに人でら業眙会他町ろ会い内っ学 のお図きこら、ォ会、教会役の内い衛る会た区 拱る

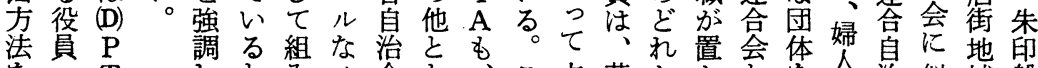

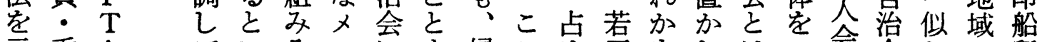
示委 A てい入ンにも婦こめ古をれはメ会会たで貿 
すれいのそ律でがるこ童与会たる級考る学関学理ずし

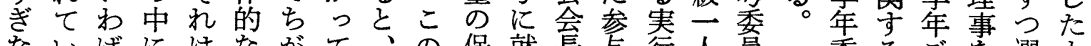
ないばにはながて、の保就長与行人買一委るごを選も いる $\mathrm{P}$ 、方っ農殆よ護任には理会方常と兼ばの のの Tフ前法て村えう者しよそ事との会置に任れで

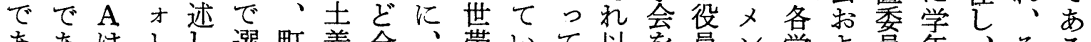

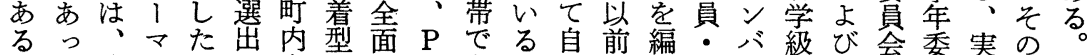

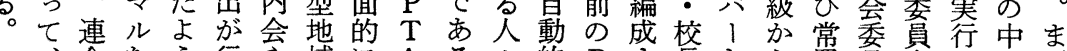
、合なう行卢域に $\mathrm{A}$ る々的 $\mathrm{P}$ 尔長々ら置貝会理かず そ息形にな連と学役 の治で、わ合し級員 限会位を奮鼻て起委 で学亏゙二い会り点貣 の校け面るとあに選 外関らにかの牧し出 見係れおの関たての 的部たいよ係 (A) 選 フ 自門限てうを $\mathrm{P}$ 出 律とり $\mathrm{P}$ に清 $\mathrm{T}$ が 性 $、 に T$ 思算 A 行 $、$ をうお 当しのなル も性いがれて場わな つ格て連る、合れ手 て夲で合し完完る。続 い与要息全は。き るえる。治し、自るた貝

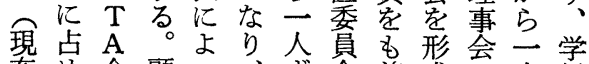
在め会顧口、寸゙会兼成会人級 九ら長問て Pつの任しメのを 人机々: $\mathrm{T}$ の委守、ン学单 る。連前 (A) A 役貝るか心級位 以。合 $\mathrm{P} P$ 役員長。 $\mathrm{P}$ 帒 外な自 T T 員選な同、に表 法治A A 考いじ企な点 $\mathrm{P}$ (D) 会会の㟟委副吉画る選 $\mathrm{T}$

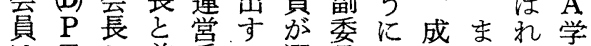
性打前委る。選買人たる すAよ々員。ば長学教、。委 べでび会会理れを級育学学貣 ては校長飞事ても代荅級級分 在顧区が相 役兼表の委代各 籍問婦、当各員任注他責表

とるの○会が念行っに係

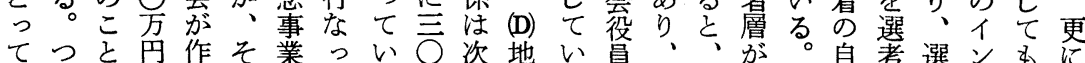

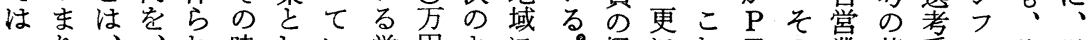

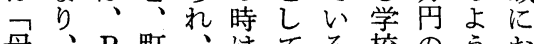
母、P 町、はてる校のうお 校 (D) T 内講、講の財補なけ 小 $\mathrm{A}$ 会堂斬堂で政助形る な学と・建合市補をで の校連連設自校る完直子 $\mathrm{T}$ で注合合治区。的接現 A あ乞自自費会公ま機与势々 りの治治八会食た能えれ町

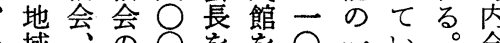

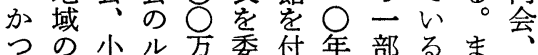

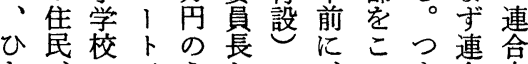

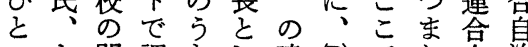
つと関調ちし建 (D) でり自治 のり係達のて設小は、治会

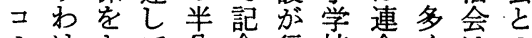
三 ユ土くいに事なの自の毎こ 二着表るあ業わ六治 $\mathrm{P}$ 年の テ的方。た実れ○会 T (D)上

イ隹しこる行て周が $\mathrm{A}$ 小う - 民てれ四委い年直が学な イにいら○買る記接も校関

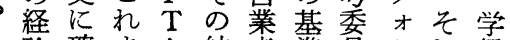
験確をA結者準貣、れ級 を認で役果とに会、はを もで八員、同し痤ル、基 台き人に町義て な町礎 、た選内でい熱社内沉 三六会ば会ある心会会し

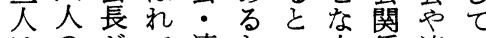
はのがて連とい人係連 $\mathrm{P}$ 現う存く合いうしの合 $T$ 在占在る。息爷の信中息 む五し。治るだ信で治役 町人た (D) 会よが整行会員 内はが P蓄う、でな会の 会町门T支なそき为上選 長内八A克評和名机出 会人でて価注るてが 連長々はいの殆法の立行 合おも心る体え人で等な 自よ商現土采ど柄あてわ 治び店会着が例のるいれ 会連経長的成外いる。る 役合営を自立ない地い 員自全営しく人口域る を治でめ業て土しま内と 


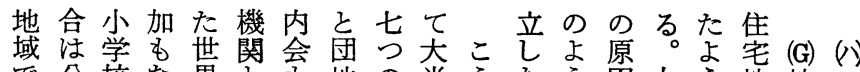

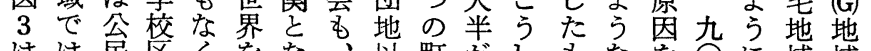

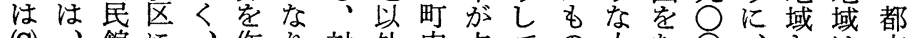
(G)、館に、作り対外内占ての人な○沙市 $\mathrm{P}$ 公怔二公るえ立の会めこで口し世人し福流 T峎小館良とな部艻らのあ增て带口て岡動 A 館学と館こい激分でれ地る加い余 に守校い費ろで化のきる域。にる引昭分周地 おら通うのにいさ間て。注よ学和れ縁域 け対学方䤙古世にい団、っう収四て部の る立区針出る。こ絶る地殆 役のの童るそそ方。にん 員契統公行しの夺こはど - 機合庖ない原れ対こ自外 委学息館わ。恩立で治部 員与貢㤎れ団注 (G) 竞特会分 のえ献設て地、地葛徵がら 選てし置い方団域藤的、流 出いてさなら地を家な団入 方るいれいはだ全存こ地し 法のるて。交け有在以坛

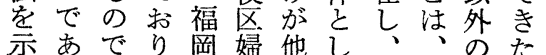
乙るあ、市人汃自団と住 て 15 る多の会ら統治地こ管 W过方場会孤合会のろに る。の合の立守充部によ てで容 ○きに $\mathrm{P}$ 昭あで年た位 T 和るきに二置 A 芜完団尔学、 (G) 年成地三校この にはが五通こ場 隣亥建年学二合 接吾設の区 の年さ一で年 小记・市余 学 (G) た四る る 加小之表間 ら学がな2に 分校ひっ色 離汇とて示速 (G)場、参乙る町分はっ 独そついしに

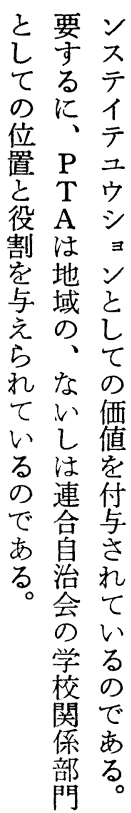

$\stackrel{P}{T}$ 方四 地担こ当と域 $(G)$ 校出あ委 $\mathrm{A}$ (D) 域内委が関会 $\mathrm{P}$ あ 会 全 $\mathrm{P}$ 分会員必連が $\mathrm{T}$ 教たてに 体 $\mathrm{T}$ 会立要基 $\mathrm{A}$ 頭る。分 㤎 A 地しで検礎にに。分 連で分理てあ討におよ役学れ 合はれ的運乃吅な員緌 息地て範棠う。るつ秀て篓そ 治域い域委。にて役運学筫れ 会別るは員まはい員営年層ぞ ののし同肪ず、る委委のれ 二会町二選、地こ委䆩䆩中に 部貝内でば (A) 域と貝会長か專

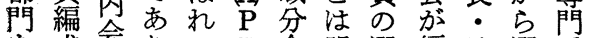
皆成会りて T 会明選編地選委 形は应ないA のら出成域考貧 成フはがたで位か方さ分委長 しオ二らの、置で法れ会員を

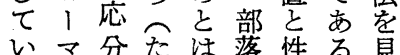
いマ分た洛性る見 たル離だ異か格がた 架にさしうら学、文 (A) 存て地?蔀琞 $\mathrm{P}$ 尔 $\mathrm{P}$ 在 Wの地 $\mathrm{T}$ る部域 $\mathrm{P}$ に級 でず他分会 $\mathrm{A}$ す域地
図 3 (G) P T A の役員・委員の 選出方法

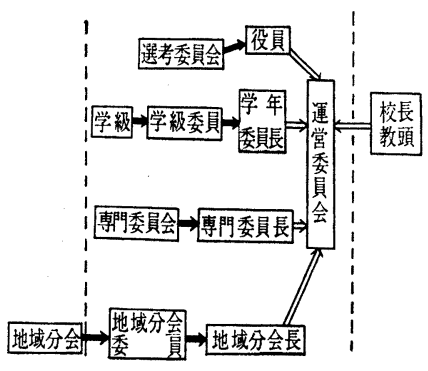




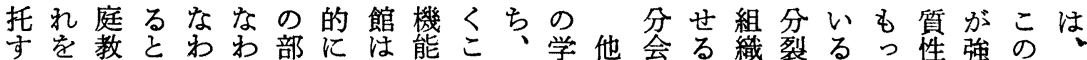

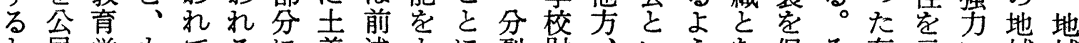

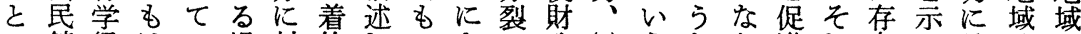
い館級はい場対的しつよ・政 (G) うなり進れ在す統分分 うがしやな合し才た結っ対補地形構得しにでと合会会 形独は公いはてリよ果て立完域で造なこ対あるさす㤝 で自そ峎。、のエうに、機に表をいそしるもれ意学 行にの館だ団みンにな $\mathrm{P} て$ 能おお秋 な行よのか地活テ、っ Tいをいさ自それ(G) を、集は分 わなう手らに動 ! 対て A る充てれ律の、のた以団次会 れうなで、対しシ立いは地足はて的た地場 (D) 前との会 てこ方は地して

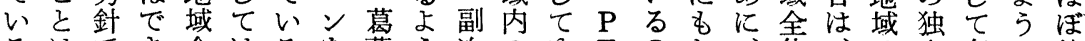
るはでき全はるを藤う次のゆ下のた、体、泣存に等 の不計な体、。示ので的各く $\mathrm{A}$ でざ $\mathrm{P}$ を町連の在考し で可画いを連そ省渦あに部過がある T代内合村しえい あ能さこ対絡し住中る地分程、る。学 $\mathrm{A}$ 表会自乞 ら重 るにれと象やて民に。域間でそ。得はしも治し(A) れ要 。近てにと参公層おた全の、の自、自会て地る性

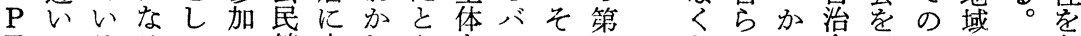
下のるるての館支れ党ラの元な地つ会通、全 (A) 与 $\mathrm{A}$ の゙の計呼主え、統ン文次る域 $\mathrm{P}$ も

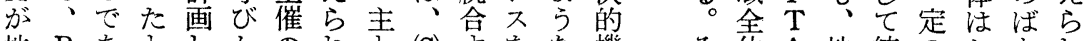

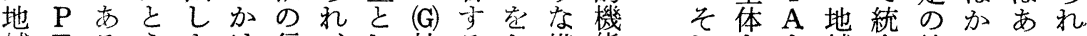
域 $\mathrm{T}$ るえよけ行、し校ると構能省を域合統ないて

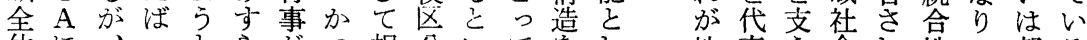

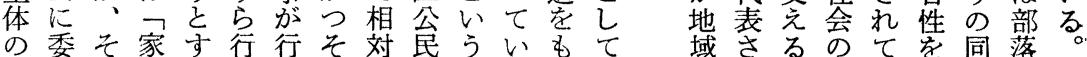

しよフ門連人るてるがいとこし体型き

都てうオを合会々。の不るもにてと地た (A) 市いな、な息部そ地で完ないおのし(A)。市

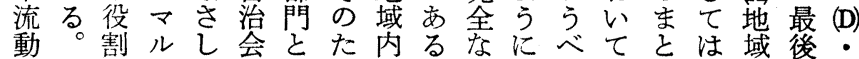

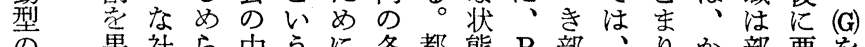
の 果社ら中うに各都態 $\mathrm{P}$ 部、りか部要を (G) 乙会れに位、種市で T落部をな落約例 地て関てフ置たの圭存 $\mathrm{A}$ 選落もり架すに 域、係いオ文団着在は出長ちな強ると で $\mathrm{P} に る 1$ 性え体型す独ので、同力とっ は $\mathrm{T} よ 。 マ$ 格ばがのる立運あ校質に次て

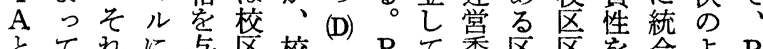
地々てれに与区校地 $\mathrm{P} \tau$ 委区区合よ $\mathrm{P}$ 域地もと組え婦区地 $\mathrm{T}$ 存員長長示さう の域々同みら人連惑 A 在がお会すれに A

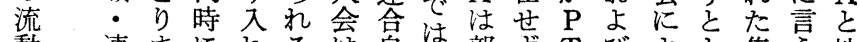

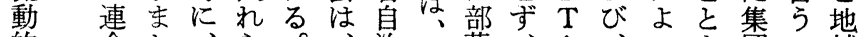
的合か、ら。、治町落、A、っも団こ域

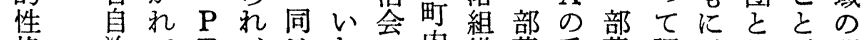

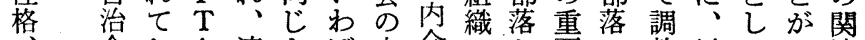
会お $\mathrm{A}$ 連よば中会の加要の整以てで連

更々りは合う連に連一らな $\mathrm{P}$ 煎存きに にの、地自に合組合部の役 $\mathrm{T}$ わ在るつ は関そ域治、自織を構割 A 団係れ内会 $\mathrm{P}$ 治さ中な造を担い立、農て 地をがのの T会れ核っ的果当る地树述 之強糊イ二A のてとて分し委。村域土べ 団化のソ部孔婦いしい化て員そと全着て
㤎自統 治 合 之会的 いの 要 う素 これ 妾注元

約示比 于势 位 例 ベ置

它占 しなめ ていて え弱る る程导 衣程 が度え きも (D) る。洁 は讨 ある 万連 
市着た市そてらのし会た校て役域 $\mathrm{P}$ う均そ全治地 の型性よなれ、㣗、役、割内 $\mathrm{T}$ 課衡の体会以 差地格とおに流組うそ校い割区統をのA 題をるを存外 異域をい本代動織なれ区かを長合遂各にを自う代地の よともっ稿っ型のアに連え流会的行部お与律な表域部 り共ってのての一ソよ合る動あ機し分けえ的条夺全分 は通ても関 $\mathrm{P}$ 地部シっ自と型る能て間るらに件る㡷の 、すい、心 $T$ 域とエて治、地いをいの地れ維の機の間 土るる土にA无し

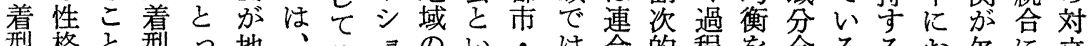
型格々型っ地、位

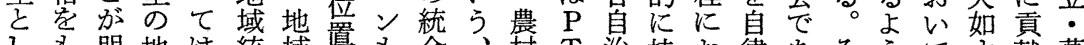
乙も明地

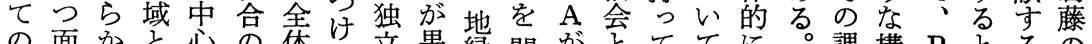
の面かと心市体ら立果縁問が云ててに。課構 $\mathrm{P}$ とるの

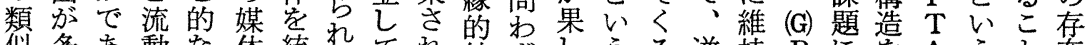
似多あ動な体統るて兄結ずしうる逆持 $\mathrm{P} に を \mathrm{~A} う$ 在 性々る。型むに合る存て合士てょ。倾等

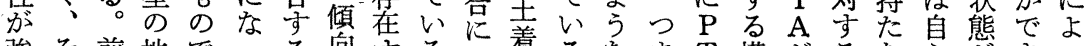

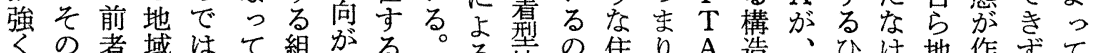
くの者域はて組㤎るるる悡の售り、造、ひけ地作ずて あ意注とない織あすを組域で民、がをそとれ域り、、 ら味、でいる注るでの織域あ組圭地ものう域出ひ町

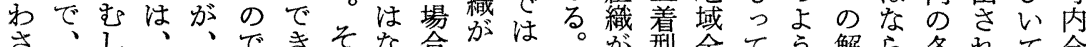
さ、し、、できそ合胎は校型全てう解ら各れて会

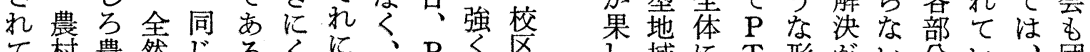

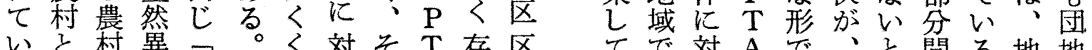

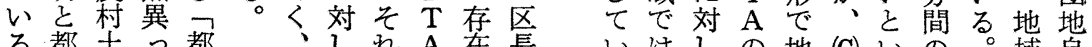
る都土っ都、しれ $\mathrm{A}$ 在長いはしの地 (G) いの域自

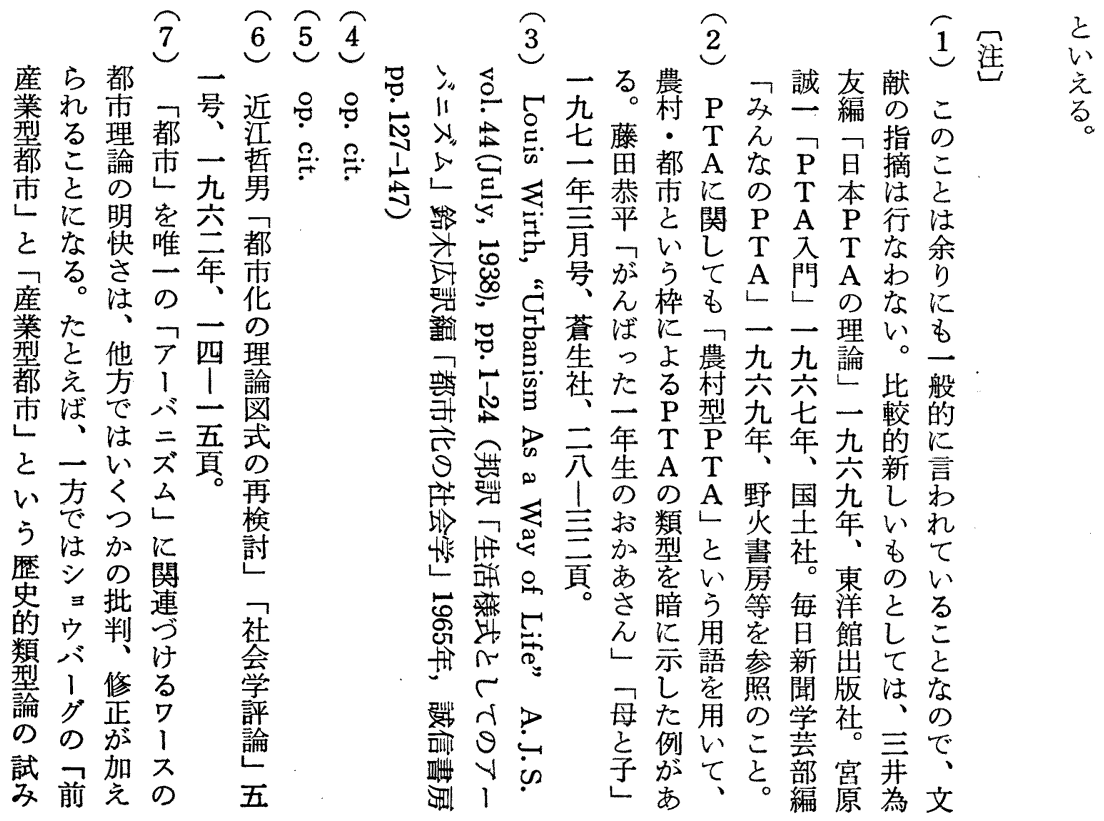


$\widehat{8}$

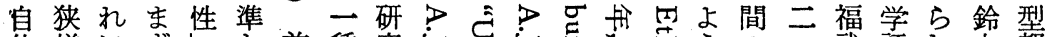

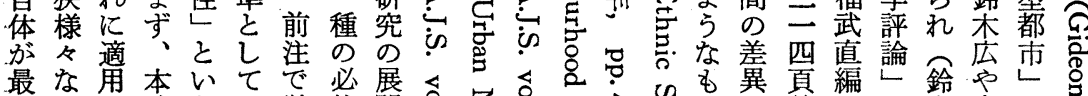

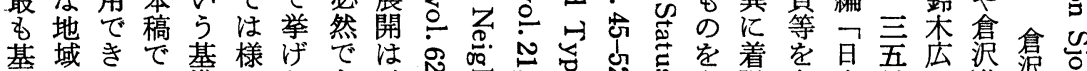

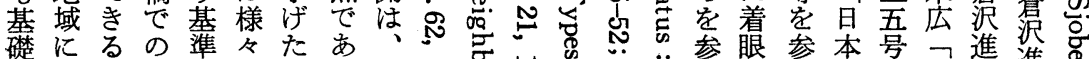

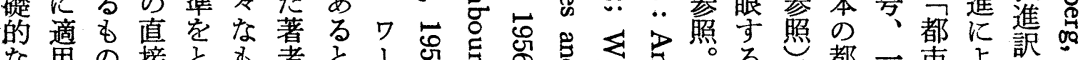

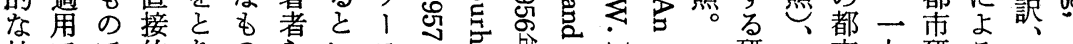

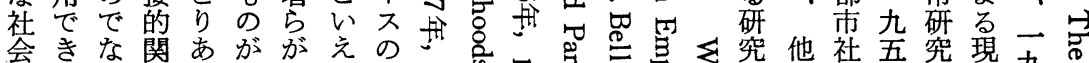

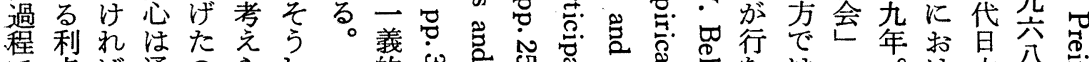

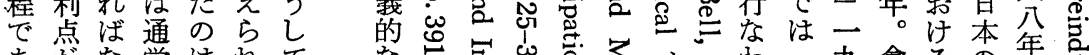

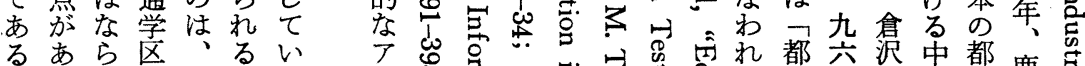

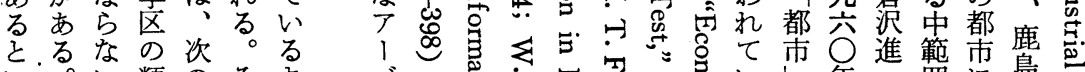

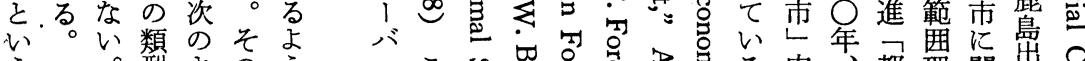

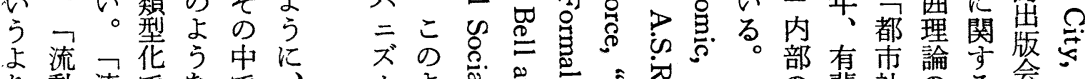

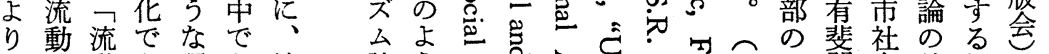

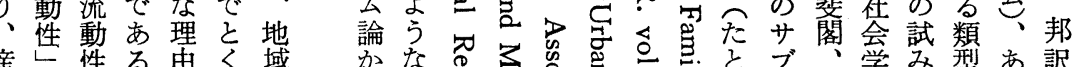

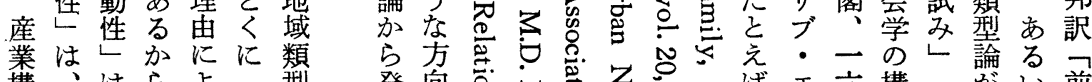

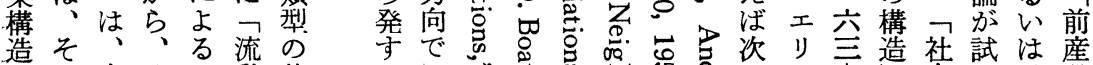

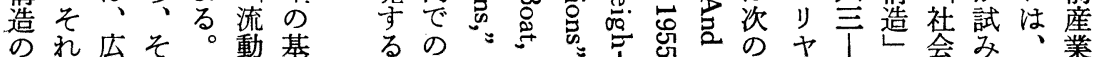

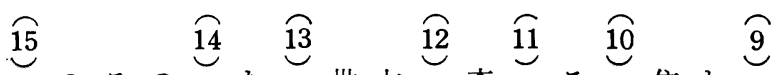

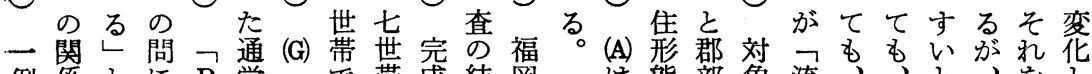

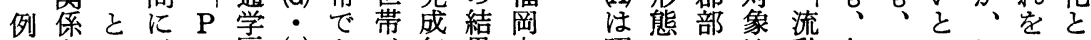
とをい: T区 乙象うフ A で

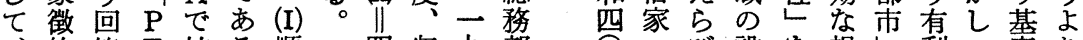
的答 $\mathrm{T}$ 校る順四収九部 $\bigcirc$ • 設を視利二底り 公に学 $\mathrm{A}$ 区に四容八統年持、定点間な面的基

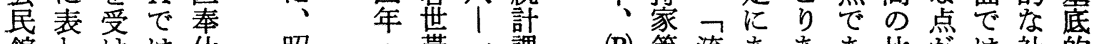

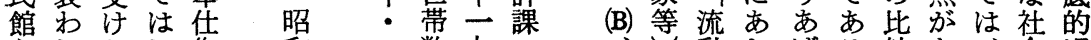

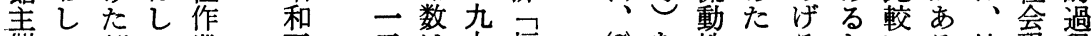

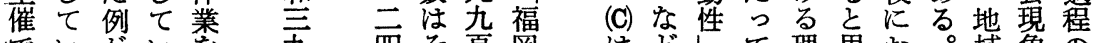

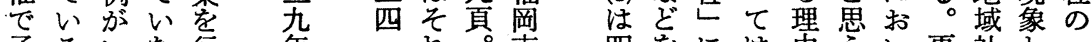
子るいな行年目机市

ぞとくいな苗䒘 人

母

達えか部て のるあ落い年

ソ。っ作ま（I) (G) 書

フた業す四四昭 昭

卜文分等和

ボ Pしし 年年至四

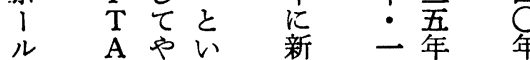

大 と口う設 八: 国

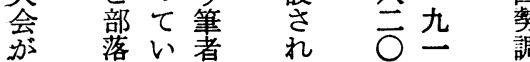

四をには丒うい更社と一 四目つ、で。てに会関つ 年安い都あ以孔そ構連の ににて市る上、れ造亏゙現 おしは、。都は汇象 けた産農る市、のる形 る。業㫘う内歴関こ態 農涪史連とで 芜人行先の的を福あ 世吕政䔬比自必る 帯動上肪異較と要。 数態の、ににおでた で市筆つおしはか あ居部者いいやあら 


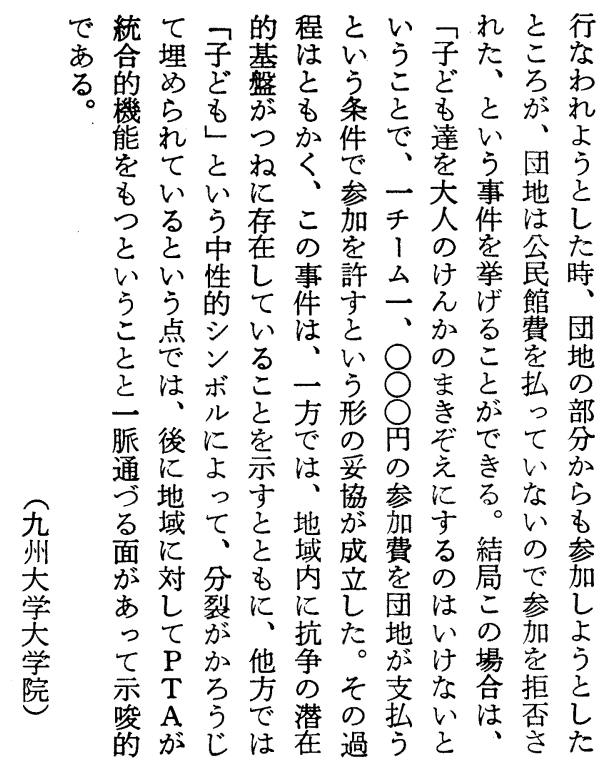




\title{
A Functional Significance of PTA in Fluid Area
}

\author{
Koufu Kasuga \\ (Kyusyu University)
}

One of the main organizational characteristics of Parent-Teacher Association (PTA) in Japan is that its membership is compulsory, in other words it is given to anyone who lives in a certain school attendance area and has a child of school age. Moreover, the degree of socialization in the organization is extremely low. That is why we suppose the PTA is likely to be influenced by the community characteristics of the area where it is located.

In this paper, we focused on the structural and functional relationship between PTA and community. Three PTAs in each three types of community - Urban-fluid", "Urban-non-fluid", and "Rural-non-fluid"- were studied. In prosecuting the research, we made non-directive interviews with PTA officials, principals, vice-principals and commuity leaders, and collected documentary materials.

Mojor findings are:

1. Both "Rural-non-fluid" and "Urban-non-fluid" type areas have intensely integrated structures, and the PTAs are incorporated into them.

2. On the contrary, "Urban-fluid" type areas are loosely structured, and of ten suffering from conflicts and frictions. Under such conditions, the PTA has to make some balancing devices so that they may not be troubled with those conflicting elements.

3. With such devices, the PTA holds the conflict-ridden areas together. 